\title{
Ediacaran Discs from the Jodhpur Sandstone, Marwar Supergroup, India: A Biological Diversification or Taphonomic Interplay?
}

\author{
Purnima Srivastava \\ Centre of Advanced Study in Geology, Lucknow University, Lucknow, India \\ Email: purnimasrivastava_51@rediffmail.com
}

Received August 25, 2012; revised September 23, 2012; accepted October 24, 2012

\begin{abstract}
The noncarbonaceous Ediacaran discs of variable morphologies from the Jodhpur Sandstone Formation of the Marwar Supergroup, western Rajasthan, suggest different biologic affinities of plant and animal kingdom. These discs are commonly preserved on the bedding surfaces of siliciclastic sandstone and shale in strong positive relief and appear to possess a flexible to rigid body. Discs assignable to Aspidella, Cyclomedusa, Nimbia and Heimalora; all possibly inclining towards cnidarian affinity are being reported from the sandstone beds in Sursagar area. Variable morphologies among discs preserved in siliciclastic shale beds from the Artiya Kalan area support scyphozoan affinity (earlier named Marsonia from the same locality) and cnidarian affinity for small discs comparable with Funisia (considered being the first animals having sexual reproduction). Disc's morphologies also suggest ephyra stage of Aurilia (a cnidarian form) or budding stages of some fungi, like Germinosphaera (multicellular benthic fungal fossils) and noncarbonaceous discs with well preserved wrinkles and folds like in Chuaria. Discs from the Jodhpur Sandstone, may at times display taphonomic interplay, but consistency and repetition in morphology support variable biological affinities representing diverse assemblage and advance ecosystem prevailing during Ediacaran period. A degree of genetic variability can be expected within any taxa, and this may be compounded by preservation factors affecting the Jodhpur Ediacaran discs. Sudden increase in size or gigantism is a common feature of Ediacaran life, which is evident in case of Jodhpur discs also. On the basis of fossil assemblage, the Jodhpur Group (the Marwar Supergroup) is regionally correlated with the Bhander Group of the Vindhyan Supergroup and Krol Group of Lesser Himalaya. Globally, the assemblage is comparable with the Long Mynd Group, Shropshire, UK, Fermuse Formation Newfoundland, South Australia, Russia and Norway.
\end{abstract}

Keywords: Jodhpur Group; Marwar Supergroup; Ediacaran Discs; Noncarbonaceous; Diversification; Taphonomic

\section{Introduction}

Ediacaran fossils document an important evolutionary episode prior to the "Cambrian Explosion". It holds critical information regarding early macroscopic evolution and emergence of multicellularity. Recent developments indicate that Ediacaran fossils epitomize a phylogenetically diverse biosphere, very likely including animals, protists, algae, fungi and others. Their simple ecology is dominated by epibenthic osmotrophs, deposit feeders and grazers, but few if any predaters [1]. It was suggested that variations between many of the species and even some genera are facets of preservation and many taxa are actually synonymous [2].

Recent advances in palaeoecology of ediacaran organisms are of close relevance to the evolutionary radiation in the Ediacaran-Cambrian transition [3]. Discoidal fossils, despite being the oldest and most common elements of Ediacaran biota have not received their fair share and attention [4]. Attachment discs of stalked forms adhere to the microbial mats at sediment-water interface, and forms without upper parts have been reported from most of the Ediacaran assemblages all over world.

In present paper discoid fossils from the Jodhpur Sandstone, the Marwar Supergroup, exhibiting wide size range and morphological diversity, are comparable to some extent in morphology with the other established simple or advanced forms of the Ediacaran biota of variable affinities. The paper also highlights whether morphological diversity is governed by taphonomy or it is biological. In addition to discoid fossils, co-occurring complex morphologies (like macro algal fossils assignable to Chlorophycean and rhodophycean algae) suggest a heterogeneous mixture of benthic discoidal organisms, including algal, fungal, actinian grade cnidarians or po- 
riferans, rather than a part of complex Ediacaran forms.

\section{Geological Setting}

The Marwar Supergroup, previously known as Trans Aravalli-Vindhyans comprises of undisturbed and unmetamorphosed sedimentary rocks occurring on western side of NE-SW trending Aravalli Mountains. Age of the Supergroup is considered to be younger than $681 \mathrm{Ma}$, as it rests unconformably on Malani Igneous Suite, which is dated as 779 - $681 \mathrm{Ma}[5,6]$. The upper age for the Supergroup is Cambrian, as Ediacaran-Cambrian boundary has earlier been suggested in Bilara Group on the basis of isotope data [7,8]; whereas on the basis of Treptichnus pedum (an Ediacaran-Cambrian boundary marker fossil burrow), it has been suggested in Nagaur Group [9]. Acritarchs [10] from sub-surface core data, trilobite traces [11] and Priapulid worm-like fossils [12] reported from the Nagaur Group (youngest Group of the Marwar Supergroup) suggests the lower Cambrian age. The supergroup is divided into three groups. In stratigraphic order they are: the Jodhpur Group, Bilara Group and the Nagaur Group (Table 1). The Jodhpur and Nagaur Groups are comprised of siliciclastic rocks whereas the Bilara Group is represented by calcareous sediments (Table 1). The Jodhpur Group is further divided into two formations, Pokran Boulder Bed and Jodhpur Sandstone Formation in stratigraphic order [13]. Present fossil assemblage is reported from the Jodhpur Sandstone exposed in Sur Sagar and Artiya Kalan areas in Jodhpur district, western Rajasthan (Figure 1). The lithology of study area in Artiya Kalan is represented by 16 - 17 meters thick brownish maroon shale intercalated with grayish white quartzitic sandstone beds. Beneath the fossil bearing beds, light pink coloured medium to coarse grained sandstone is exposed (Figure 2(a)). GPS values for the fossil bearing beds are $26^{\circ} 33^{\prime} 10.6^{\prime \prime} \mathrm{N}, 73^{\circ} 24^{\prime} 54.1 " \mathrm{E}$.

In Sursagar area, the lithology is represented by yellowish brown to pinkish brown medium to fine grained sandstone (Figure 2(b)). In thin sections the discs exhibit sharp contacts. The fossil bearing horizon in Sursagar area is considered to represent shallowing upward cycles, developing under near-shore beach environment [13].

In general hypersaline lagoonal, marginal marine and shallow water fair-weather wave base environment of deposition have been suggested for the fossil bearing Jodhpur Sandstone [14]. Since Ediacaran fossils have already been reported from the Jodhpur Sandstone Formation exposed in Sur Sagar area [11,15], and EdiacaranCambrian boundary has been marked in Nagaur Group [9], Ediacaran age for the fossil bearing horizon is undoubted.

\section{Morphology of Ediacaran Discs from the Artiya Kalan Area}

Noncarbonaceous Ediacaran discs named as Marsonia, assignable to scyphozoan affinity (not well preserved) have been reported earlier from the Artiya Kalan area [16]. The present assemblage reports ediacaran discs possibly of both animal and plant affinities. The morphologies of these forms are:

- Circular discs ranging in size from $3 \mathrm{~mm}$ to $4 \mathrm{~cm}$ (8 specimens measured) exhibit prominent quadriradial canals, suggestive of scyphozoan affinity (Figures 3(G), 4(A) and (B)).

- Cluster of small-sized discs without any ornamentation (Figure 4(G)) well comparable with Beltanelliformis [17], occur in present assemblage in association with Arumberia-like structures (Figure 3(C)). Diameter of discs ranges between 1 - 5 mm (35 specimens measured). These organisms are considered to be the most primitive forms amongst Precambrian metazoans.

- Cluster of small-sized discs with very prominent centrally located tubercle and outer ring like structures (Figure 4(F)), well comparable with an ediacaran animal fossils Funisia, first reported from Australia and considered to be the first animals with sexual life cycle [18]. The outer diameter of disc ranges between

Table 1. Lithostratigraphic succession of the marwar supergroup, western rajasthan.

\begin{tabular}{llll}
\hline Supergroup & Group & Formation & Lithology \\
& Bap boulder beds & \\
\hline Nagaur group & Tunklian sandstone & Brick red sandstone, siltstone \& red claystone \\
& Nagaur sandstone & Brick red sandstone, siltstone \& red and green clay beds \\
Marwar supergroup & Bilara group & Pondlo dolomite & Cherty dolomitic limestone \\
& & Dhanapa dolomite & Dolomitic limestone with cherty lenses \\
& Jodhpur group & Podhpur sandstone & Reddish yellow gritty sandstone with reddish brown clay beds \\
\hline
\end{tabular}

Malani Igneous Complex/Aravalli Rocks (780 - $681 \mathrm{Ma)}$. 


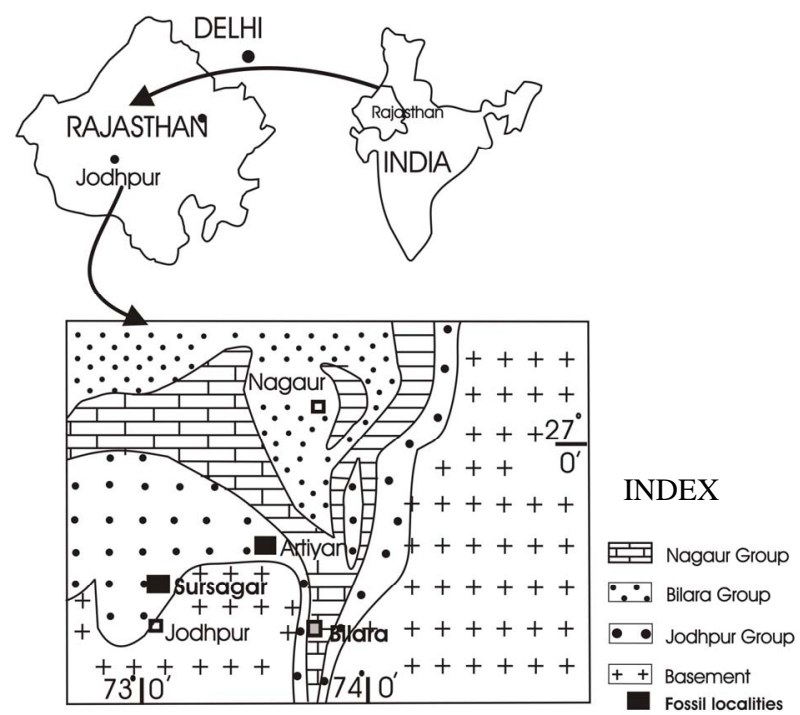

Figure 1. Geological map of the Marwar Supergroup, Western Rajasthan (all starting with caps) exposed in Artiya Kalan and adjacent areas (modified after Raghav et al., 2005).

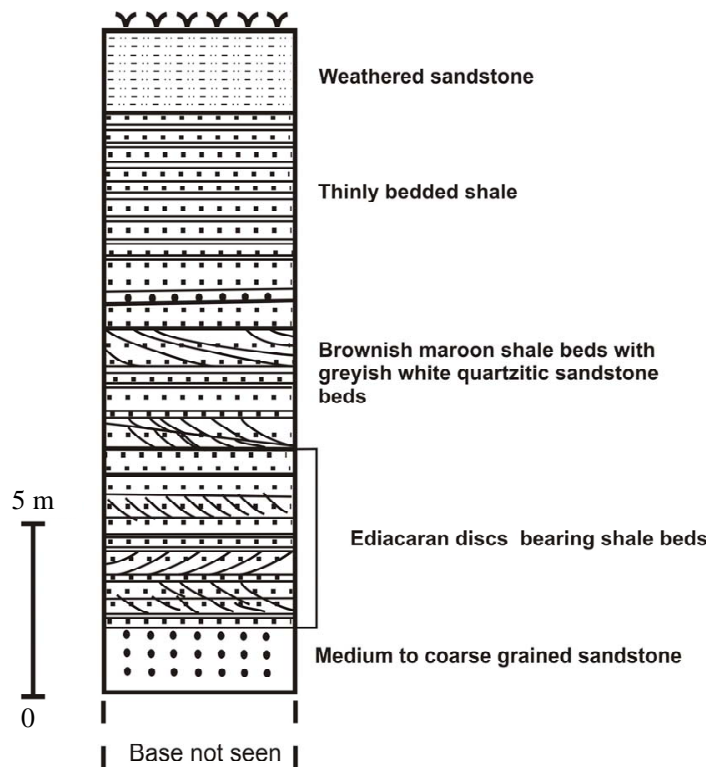

(a)

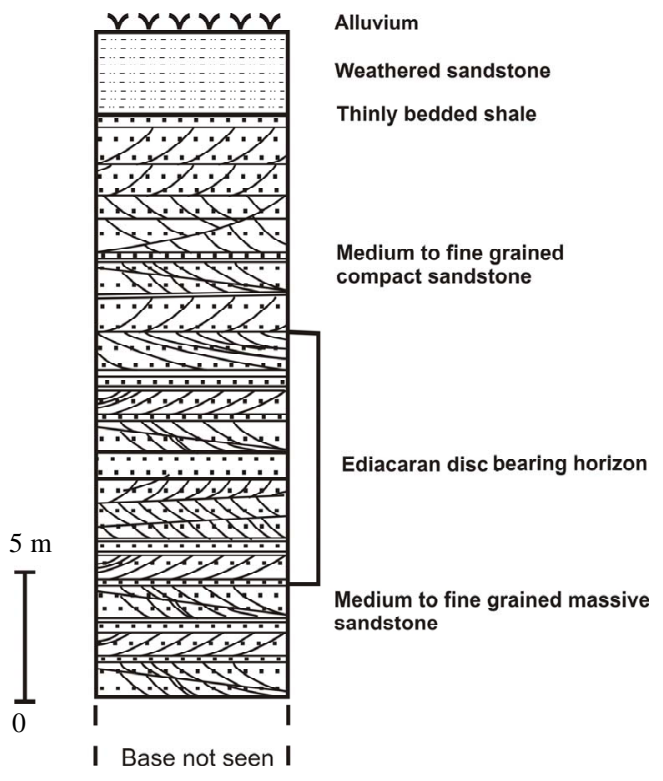

(b)

Figure 2. (a) Lithocolumn of study area in Artiya Kalan, Jodhpur District, Rajasthan; (b) Lithocolumn of study area in Sursagar, Jodhpur District, Rajasthan.

0.5 - $1.0 \mathrm{~cm}$, and inner tubercle like structure ranges 2 $4 \mathrm{~mm}$ in size (21 specimens measured). The sponge or Cnidarian affinity for these forms has been suggested [18].

- An elliptical disc (long axis varies between 1.5 - 5 cm, 4 specimens measured) with one end slightly tapered (Figures 3(F) and $\mathbf{4 ( C )}$ ) shows some resemblance with ephyra stage of Aurilia (also known as moon jelly- fish). It is believed that the organism undergoes a complex life cycle, including a larval medusae or ephyra stage (Figure 3(F)) and mature medusa. This particular specimen can also be compared with budding like structures of organic walled microscopic acritarch Germinosphaera, considered to be a fungal form [19]. A dispersal stage like morphology (Figure 4(D)) seems in a state to disperse the small larva-like structure or polyps, which in due time supposed to develop into adults.

- Discs with well preserved division stages or union of two gametes like structures, also resemble to some extent with higher fungi. Progressive stages represented by specimens shown in (Figures 3(B), (D), 

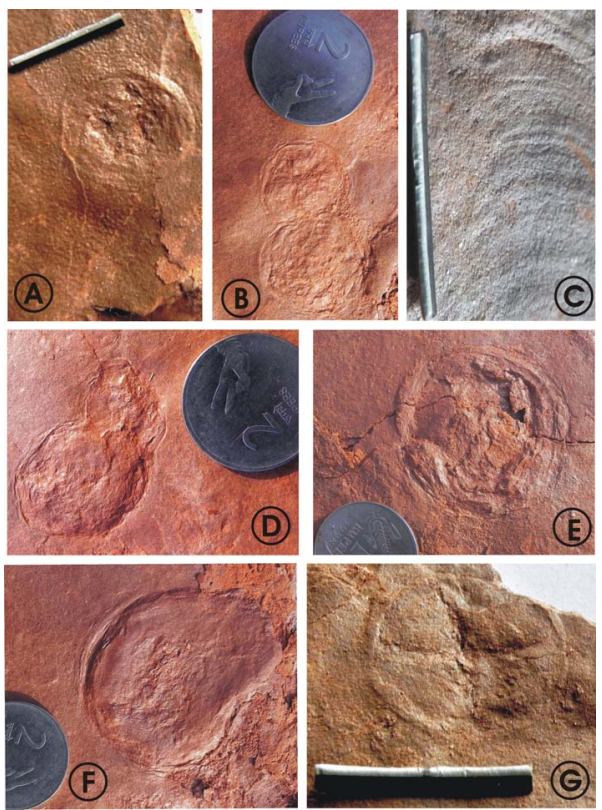

Figure 3. Noncarbonaceous discs from the Jodhpur sandstone in Artiya Kalan area. Scale bar in photo $\mathrm{A}, \mathrm{C}$ and $\mathrm{G}=$ $2 \mathrm{~cm}$, Coins of rupee one and two have been placed for the scale. Two rupee coin measures $2.7 \mathrm{~cm}$ and one rupee coin measures $2.5 \mathrm{~cm}$. (A) Circular disc with tube like projection, tapered at rear end; (B) Budding or division stage, exhibiting merged wall between them; (C) Arumberia-like structure; (D) Division stage; (E) Chuaria-like disc with well preserved folds and wrinkles; (F) Elliptical disc with ephyralike stage of Aurelia (moon jellyfish); (G) Disc with prominent qudriradial canals comparable with Scyphozoan affinity.

And 5(D)). There is also a possibility that the morphologies are division stages of algae as observed in extant chlorophycean form Cosmarium [20].

- A disc/vesicle like structure (Figures 3(A) and 4(A)) with central vacuole projected into an elongated tubelike structure (may be a rhizoid), tapered at rear end in one specimen can be compared with a division stage of extant chlorophycean alga Protosiphon [20].

- Discs with well marked folds and wrinkles, which are characteristic features of Chuaria are present in the assemblage. The only difference in specimens of present assemblage is their larger size and absence of carbonaceous matter (Figures 3(E) and 5(C)). Larger size can be justified by the gigantism in general life forms, during Ediacaran period.

- Circular discs with numerous radial ridge-like structures radiating from the centre (Figures 4(E) and 5(A)). The morphplogy is comparable to some extent with ediacaran fossil named as Irridinites [21], belonging to coelenterates. Almost similar morphology was earlier described as a trace fossil Medusinites aff. [17] and was also considered as a polyp [22].

- Figure 5(B) exhibits peculiar jellyfish like morphol-

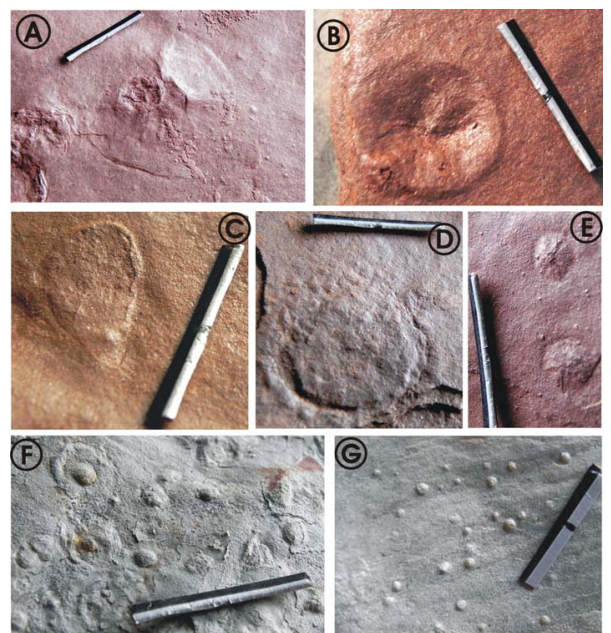

Figure 4. Noncarbonaceous discs from the Jodhpur sandstone in Artiyan Kala area. Scale bar in all photographs = 2 cm. (A) Disc with moderately preserved quadriradial canal (Scyphozoan affinity) and in left corner disc with tube like projection as in extant chlorophycean alga Protosiphon; (B) Disc with quadriradial canal (Scyphozoan affinity); (C) Baloon or cone shaped noncarbonaceous form comparable to an ephyra stage of Aurelia; (D) A dispersal stage like morphology comparable to ephyra stage of Aurelia; (E) Two small discs with radial ridge-like structures comparable to some extent with Irridinites (coelenrerates), or Medusinites (a polyp of cnidarian affinity); (F) Circular disc with centrally located embossed tubercle, comparable with Funisia; (G) Beltanelliformis in association with Arumberialike mats.

ogy with Rhopalium or bell and tentacles like structures.

- There are specimens exhibiting frond like morphology (Figure 5(E)), as fronds of Charniodiscus also show ornamentation as shown by Artiya Kalan specimens. Although complete specimen with hold fast has not been found in present assemblage.

\section{Ediacaran Discs from the Sursagar Area}

In Sursagar area the ediacaran discs occur on bedding surface of the yellowish pink sandstone. The morphologies can be represented by:

- Circular to subcircular discs with very prominent inner circular body assignable to Aspidella of cnidarian or jellyfish affinity (Figures 6(A), (B) and (E)). The present assemblage comprises one of the biggest disc measuring $37 \mathrm{~cm}$ (Figure 6(A)).

- Circular disc with radial and concentric markings assignable to Cyclomedusa of medusa or jellyfish affinity (Figure 6(D)).

- Circular discs with processes or tentacles like projections identified as Heimalora, categorized among sea anemones or medusoid cnidarian affinity (Figures 6(C) and (F)). 

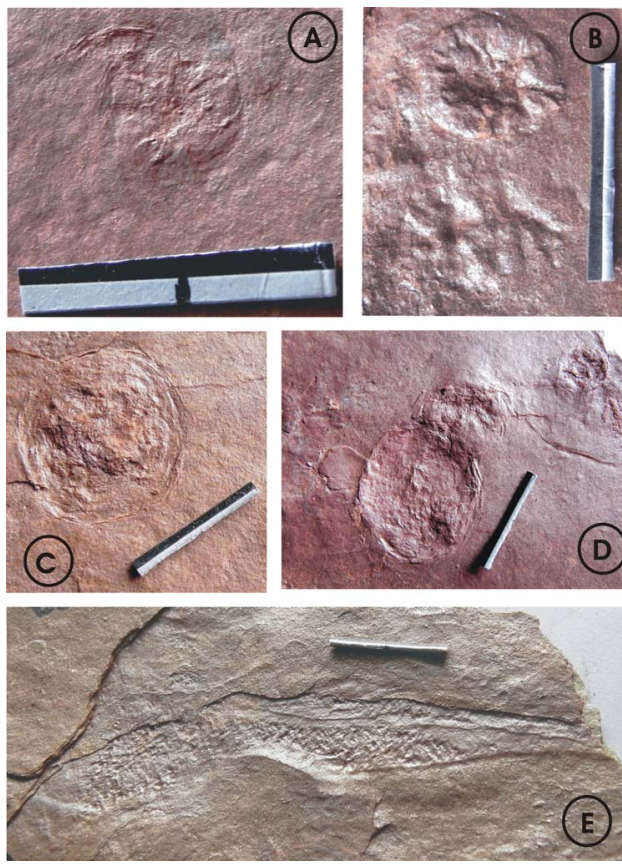

Figure 5. Noncarbonaceous discs from the Jodhpur Sandstone in Artiyan Kala area. Scale bar in all photographs $=2$ $\mathrm{cm}$. (A) Circular disc with radial ridge-like structure, radiating from the centre. Morphology is comparable with Medusinites; (B) Jellyfish like morphology with structures resembling Rhopalium or bell like tentacles; (C) Chuarialike disc with folds and wrinkles; (D) Division stage; (E) Frond-like structure.

- Elliptical discs with inner circular body and outer sheath like structure is very difficult to compare with any known ediacaran fossil form.

\section{Discussion}

Domination of soft-bodied metazoans without mineralized skeletons (represented largely by coelentrates, which may be solitary or colonial), fossils associated with microbial mats, gigantism of life forms and exceptional preservation of casts and moulds are the few characteristic features of Ediacaran fossils all over world, which is distinctly visible in discs of present assemblage. The Ediacaran period can be characterized as a time of explosive development of medusoids and coelentrates [23]. However, scarcity of Ediacaran fossils in exceptionally preserved Cambrian biota, like Burgess Shale [24] points their extinction or the ecological restriction [25].

Noncarbonaceous discs from the Jodhpur Sandstone in Sursagar and Artiya Kalan areas occur on bedding surface and exhibit flexible to rigid structures. They exhibit remarkable variation in morphology and ascribed to different biologic affinities of plant and animal kingdom. Although taphonomic interplay between the flexibility, related to decay rate and surrounding sediments followed by the degree of post burial compressions may result in
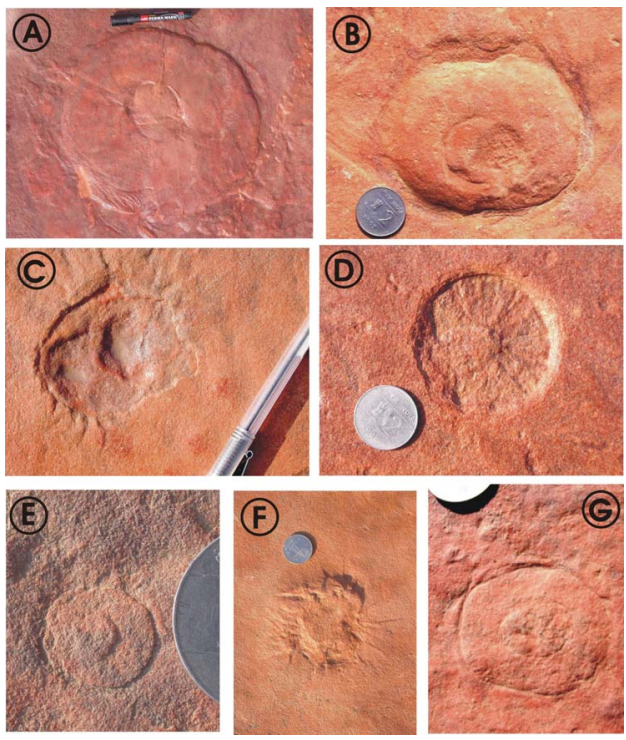

Figure 6. Noncarbonaceous discs from the Jodhpur Sandstone in Sursagar area. For Scale, coins of rupee one and two have been given, Two rupee coin measures $2.7 \mathrm{~cm}$ and one rupee coin measures $2.5 \mathrm{~cm}$. Marker pen and gel pen given in Figure $A=14 \mathrm{~cm}$ and pen given in Figure $C=14$ cm. (A), (B), (E) Aspidella, Disc with prominently preserved inner circular body; (C), (F) Heimalora, Disc with tentacles or processes radiating from the periphery of the disc; (D) Cyclomedusa, Circular disc with radiating and concentric markings; (G) Unidentified Elliptical disc with inner circular body and outer sheath-like structure.

variable morphological features of the fossils. Discs acquiring different shapes exhibit oval, ellipsoidal, egg shaped, circular, semi circular, elongated structure, with or without an intracellular mass of variable dimensions and shapes, discs with single, double or triple lamellated outer sheath like structures (Figure 6(G)). It seems that some of these structures are the result of taphonomic effect on organisms of possibly single biologic affinity. Although morphologies exhibited by most of the fossils in present assemblage are so prominent, consistent and repetitive, hence supporting the original characters. A degree of genetic variability can be expected within any taxon, and this may be compounded by preservational or taphonomic factors affecting the Jodhpur Ediacara fossils. Plasticity in morphology was present to a greater degree in the earliest, simple flora or fauna, where the genetic mechanisms may have been unable to replicate body form faithfully [26].

Specimens exhibiting morphologies comparable with discs of Chuaria (without carbonaceous matter), division stages and budding like structures as described in organic walled acritarchs like Germinosphaera and higher fungi support the plant affinity. At the same time specimens exhibiting four fold symmetry: a characteristic feature of Scyphozoans or Jellyfish and specimens resembling ephyra stage and dispersal stages-like features (Figure 
4(D)), specimens comparable with Aspidella, Cyclomedusa, Heimalora Beltanelliformis (the most primitive organisms among Precambrian metazoans, occurring with Arumberia and microbial mats) in present assemblage, support animal affinity and suggest an ecological relationship between plants and animals.

\section{Conclusions}

In present assemblage, Ediacaran discs from the Jodhpur Sandstone exhibiting variable morphologies may be facets of preservation, hence some of these forms can be categorized among synonyms and variation in morphology is simply taphonomic or preservational. Since most of the Ediacaran discs in present assemblage are preserved on bedding surface, the interplay between rigidity and flexibility of organisms, related to process of decay and nature of surrounding sediments, followed by compressions or deformation after burial resulted in visible morphologies. At the same time prominent features consistently and repetitively exhibited by a number of discoidal specimens of present assemblage are undoubtedly generic features of variable affinities. It is therefore inferred that variation in morphology of Ediacaran discs from the Jodhpur Sandstone is governed by both taphonomy as well as biological diversity among plant and animal communities, prevailing at the time of host rock sedimentation.

Globally the discoidal fossils probably account for the majority of fossils in Fermuse Formation of Newfoundland and similar assemblage from the Norway, Long Mynd Group, England and Wales. Discs in Mistaken Point have been inferred as hold fasts. Present assemblage along with other complex assemblages from the South Australia and White Sea of Russia also unequivocally contain more than one biological construction responsible for the discoidal structures.

On the basis of Ediacaran fossils reported from the Jodhpur Group and Bhander Group (Vindhyan Supergroup) exposed in Madhya Pradesh and Rajasthan, both the groups can be correlated biostratigraphically, which was supported by earlier workers also [27]. It has also been inferred earlier that during Ediacaran period, both the Basins were linked with each other through Himalayas [11].

\section{Acknowledgements}

The author is thankful to the Head, Centre of Advanced Study in Geology, Lucknow University, India, for providing basic facilities to carry out this research. She is indebted to Dr. R. Bali for his help during the course of investigation. Financial assistance from DST, New Delhi in form of a WOS-A project no SR/OY/WOS-A/ES-20/ 2008 is thankfully acknowledged.

\section{REFERENCES}

[1] S. Xiao and M. Laflamme, "On the Eve of Animal Radiation: Phylogeny, Ecology and Evolution of the Ediacaran Biota,” Trends in Ecology and Evolution, Vol. 24, No. 1, 2008, pp. 31-40. doi:10.1016/j.tree.2008.07.015

[2] T. P. Crimes and D. Mcllroy, "A Biota of Ediacaran Aspect from Lower Cambrian Strata on the Digermul Peninsula, Arctic Norway," Geological Magazine, Vol. 136, No. 6, 1999, pp. 633-642. doi:10.1017/S0016756899003179

[3] R. K. Bambach, A. H. Knoll and J. J. Sepkoski, “Anatomical and Ecological Constraints on Phanerozoic Animal Diversity in Marine Realm," Proceedings of the $\mathrm{Na}$ tional Academy of Sciences, Vol. 99, No. 10, 2007, pp. 6854-6859. doi:10.1073/pnas.092150999

[4] B. A. MacGabhann, "Discoidal Fossils of the Ediacaran biota: A Review of Current Understanding," Geological Society of London: Special Publication, Vol. 286, No. 1, 2007, pp. 297-313. doi:10.1144/SP286.21

[5] H. S. Pareek, "Quaternary Geology and Mineral Resources of Northwestern Rajasthan,” Memoir of Geological Survey of India, Vol. 115, 1984, pp. 1-95.

[6] S. S. Rathore, T. R. Venkatesan and R. K. Srivastava, "Rb/Sr Isotope Dating of Neoproterozoic (Malani Group) Magmatism from Southwest Rajasthan, India: Evidence of Younger Pan-African Thermal Event by 40Ar-39Ar Studies”, Gondwana Research, Vol. 2, No. 2, 1999, pp. 271-181. doi:10.1016/S1342-937X(05)70151-9

[7] A. Mazumdar and H. Staruss, "Sulfur and Strontium Isotopic Compositions of Carbonate and Evaporate Rocks from the Late Neoproterozoic-Early Cambrian Bilara Group (Nagaur-Ganganagar Basin, India): Constraints on Intrabasinal Correlation and Global Sulfur Cycle," Precambrian Research, Vol. 149, No. 3-4, 2006, pp. 217-230. doi:10.1016/j.precamres.2006.06.008

[8] M. K. Pandit, A. N. Sial, S. S. Jamrani and V. P. Ferreira, "Carbon Isotope Profile across the Bilara Group Rocks of Trans Aravalli Marwar Supergroup in Western Rajasthan, India: Implications for Neproterozoic-Cambrian Transition,” Gondwana Research, Vol. 4, No. 3, 2001, pp. $387-$ 394. doi:10.1016/S1342-937X(05)70338-5

[9] P. Srivastava, “Treptichnus pedum: An Ichnofossil Representing Ediacaran-Cambrian Boundary in the Nagaur Group, the Marwar Supergroup, Rajasthan, India,” Proceedings Indian National Science Academy, Vol. 78, No. 2, 2012, pp. 161-169..

[10] B. Prasad, R. Asher and B. Bargohai, "Late Neoproterozoic (Ediacaran)—Early Palaeozoic (Cambrian) Acritarchs from the Marwar Supergroup, Bikaner-Nagaur Basin, Rajasthan,” Geological Society of India, Vol. 75, No. 2, 2010, pp. 415-431.

[11] S. Kumar and S. K. Pandey, "Note on the Occurrence of Arumberia banksi and Associated Fossils from the Jodhpur Sandstone, Marwar Supergroup, Western Rajasthan,” Journal Palaeontological Society of India, Vol. 54, No. 2, 2009, pp. 171-178.

[12] P. Srivastava, "Problematic Worms and Priapulid-Like Fossils from the Nagaur Group, the Marwar Supergroup, 
India,” Ichnos, Vol. 19, No. 3, 2012, pp. 156-164. doi:10.1080/10420940.2012.702606

[13] D. S. Chauhan, B. Ram and N. Ram, "Jodhpur Sandstone: A Gift of Ancient Beaches to Western Rajasthan,” Journal Geological Society of India, Vol. 64, 2004, pp. 265276.

[14] S. Sarkar, P. K. Bose, P. Samanta, P. Sengupta and P. Eriksson, "Microbial Mat Mediated Structures in the Ediacaran Sonia Sandstone, Rajasthan, India and Their Implications for Proterozoic Sedimentation," Precambrian Research, Vol. 162, No. 1-2, 2008, pp. 248-263. doi:10.1016/j.precamres.2007.07.019

[15] S. Kumar, P. K. Misra and S. K. Pandey, "Ediacaran Megaplant Fossils with Vaucherian Affinity from the Jodhpur Sandstone, Marwar Supergroup, Western Rajasthan,” Current Science, Vol. 97, No. 5, 2009, pp. 701705.

[16] K. S. Raghav, C. De and R. L. Jain, "The First Record of Vendian Medusoids and Trace Fossil Bearing Algal Mat Ground from the Basal Part of the Marwar Supergroup of Rajasthan, India,” Indian Minerals, Vol. 59, No. 1-2, 2005, pp. 23- 30.

[17] D. Mcllroy, T. P. Crimes and C. J. Pauley, "Fossils and Matgrounds from the Neoproterozoic Longmyndian Supergroup, Shropshire, UK,” Geological. Magazine, Vol. 142, No. 4, 2005, pp. 441-455. doi:10.1017/S0016756805000555

[18] M. L. Droser and J. G. Gehling, "Synchronous Aggregate Growth in an Abundant New Ediacaran Tubular Organism," Science, Vol. 319, No. 5870, 2008, pp. 1660-1662. doi:10.1126/science.1152595

[19] N. J. Butterfield, "Probable Proterozoic Fungi," Palaeobiology, Vol. 31, No. 1, 2005, pp. 165-182.
doi:10.1666/0094-8373(2005)031<0165:PPF>2.0.CO;2

[20] B. R. Vashishtha, "Botany for Degree Students. Part-1," Algae, S. Chand and Company Limited, 1977, p. 545.

[21] M. A. Fedonkin, "Nonskeletal Fauna of the Podolian Pridnyestrovya,” In: V. A. Velikanov, E. A. Aseeva and M. A. Fedonkin, Eds., Vend Ukrainy, Nauk Dumka, Kiev, 1983, pp. 128-139.

[22] G. M. Narbonne and J. D. Aitken, "Ediacaran Fossils from the Sekwi Brook Area, Mackenzie Mountains, Northwestern Canada,” Journal of Palaeontology, Vol. 33, No. 4, 1990, pp. 945-980.

[23] B. S. Sokolov, "Organic World of the Earth on Its Way to the Phanerozoic Differentiation,” Vestrik Akademii, Nauk SSSR, Vol. 1, 1976, pp. 126-143.

[24] J. B. Caron and A. Jackson, "Palaeoecology of the Greater Phyllopod Bed Community, Burgess Shale,” $\mathrm{Pa}$ laeogeography, Palaeoclimatology and Palaeoecology, Vol. 258, No. 3, 2008, pp. 222-256. doi:10.1016/j.palaeo.2007.05.023

[25] G. M. Narbonne, “The Ediacara Biota: Neoproterozoic Origin of Animals and Their Ecosystems," Annual Review of Earth and Planetary Science, Vol. 33, No. 1, 2005, pp. 421-442. doi:10.1146/annurev.earth.33.092203.122519

[26] N. C. Hughes, "Morphological Plasticity and Genetic Flexibility in a Cambrian Trilobite," Geology, Vol. 19, No. 9, 1991, pp. 913-916. doi:10.1130/0091-7613(1991)019<0913:MPAGFI >2.3.C $\underline{\mathrm{O} ; 2}$

[27] S. Kumar and S. K. Pandey, "Trace Fossils from the Nagaur Sandstone, Marwar Supergroup, Dulmera Area, Bikaner District, Rajasthan, Indian,” Journal of Asian Earth Science, Vol. 38, No. 3-4, 2010, pp. 77-85. 